\title{
TINJAUAN MANAJEMEN SUMBER DAYA MANUSIA YANG MEMPENGARUHI KINERJA: SEBUAH AGENDA PENELITIAN
}

\author{
Eri Novari \\ UIN Sunan Gunung Djati Bandung \\ Email: erinovari@uinsgd.ac.id
}

\begin{abstract}
Abstrak
Ada semakin banyak bukti yang mendukung hubungan antara apa yang disebut performa tinggi atau komitmen tinggi praktik manajemen sumber daya manusia (MSDM) dan berbagai ukuran kinerja organisasi. Namun, tidak jelas mengapa hubungan ini ada. Makalah ini berpendapat bahwa untuk memberikan penjelasan yang meyakinkan tentang asosiasi ini, kita perlu meningkatkan kerangka kerja teoritis dan analitik dalam tiga bidang utama yaitu sifat MSDM, dan terutama alasan untuk daftar spesifik praktik SDM; sifat kinerja organisasi; dan hubungan antara MSDM dan kinerja. Sebuah model disajikan untuk mengeksplorasi keterkaitan ini. Literatur yang ada tentang MSDM dan kinerja ditinjau berdasarkan analisi untuk mengidentifikasi kesenjangan utama dalam pengetahuan dan membantu memfokuskan le prioritas penelitian lebih lanjut.
\end{abstract}

Kata Kunci: MSDM, Kinerja, Hasil, Teori, Integrasi Strategis.

\begin{abstract}
There is increasing evidence supporting the relationship between so-called high-performance or high-commitment human resource management practices (HRM) and various measures of organizational performance. However, it is not clear why this relationship exists. This paper argues that in order to provide a convincing explanation about this association, we need to improve the theoretical and analytical framework in three main areas namely the nature of $H R M$, and especially the reasons for a specific list of HR practices; the nature of organizational performance; and the relationship between HRM and performance. A model is presented to explore this connection. Existing literature on HRM and performance is reviewed based on analysis to identify key gaps in knowledge and help focus further research priorities.
\end{abstract}

Keywords: HRM, Performance, Results, Theory, Strategic Integration.

\section{A. PENDAHULUAN}

Dampak dari manajemen sumber daya manusia pada kinerja telah menjadi masalah penelitian yang dominan dalam berbagai bidang. Telah ada banyak penelitian yang menunjukkan hubungan positif antara manajemen sumber daya manusia (MSDM) dan kinerja, memberikan dorongan kepada mereka menganjurkan kasus ini pada pendekatan berbeda dalam pengelolaan sumber daya manusia. Sementara studi ini mewakili tanda-tanda kemajuan yang menggembirakan, kecanggihan statistik tampaknya telah ditekankan dengan mengorbankan kekakuan teoritis. Akibatnya, penelitian ini tidak aditif, kecuali dengan cara JURNAL PAPATUNG: Vol. 3 No. 1 Tahun 2020 
yang sangat umum. Tujuan saya dalam makalah ini adalah untuk menyajikan bentuk agenda penelitian yang berusaha untuk memperkenalkan kembali teori ke dalam debat empiris dan menggunakannya untuk meninjau beberapa temuan empiris yang muncul.

Jika kita ingin meningkatkan pemahaman kita tentang dampak MSDM pada kinerja, kita perlu teori tentang MSDM, teori tentang kinerja dan teori tentang bagaimana mereka terhubung. Minat dalam MSDM dan kinerja sebagian mencerminkan pandangan bahwa perdebatan tentang teori MSDM telah menjadi agak introspektif dan membosankan. Mungkin hanya ketika data empiris mulai muncul barulah kita menyadari betapa pentingnya teori itu. Saya akan mulai dengan mengulas secara singkat di mana kita berpijak pada teori-teori MSDM, kinerja dan hubungan antara MSDM dan kinerja. Saya kemudian akan meninjau beberapa literatur terbaru dalam kerangka sederhana. Akhirnya, saya akan menguraikan masalah yang muncul dari ulasan ini dan menyoroti beberapa perkembangan yang perlu terjadi dalam teori dan praktik jika kita ingin meningkatkan pemahaman kita tentang MSDM dan kinerja.

\section{B. LANDASAN TEORI}

\section{Manajemen Sumber Daya Manusia}

Dalam setiap studi empiris, kita perlu memiliki pandangan yang jelas tentang variabel independen kita. Saat ini kita hanya memiliki kebingungan. Tampaknya ada tiga kategori luas teori tingkat umum tentang MSDM dan sejumlah teori yang lebih spesifik dan konkret tentang bidang kebijakan dan praktik tertentu, seperti kualitas, komitmen, dan upah terkait kinerja. Tiga kategori teori dapat diberi label strategis, deskriptif dan normatif.

Ini terutama berkaitan dengan hubungan antara berbagai kemungkinan kontinjensi eksternal dan kebijakan dan praktik SDM. Beberapa penelitian UK paling terkenal dalam kategori ini telah dilaporkan oleh Hendry dan Pettigrew (1990) yang perhatian utamanya adalah untuk mengidentifikasi dan mengklasifikasikan pengaruh lingkungan utama pada MSDM. Dalam pekerjaan mereka, kebijakan dan praktik MSDM menjadi, dalam arti tertentu, variabel dependen, dinilai dalam hal seberapa baik itu sesuai dengan konteksnya. Hipotesis implisit tetapi belum diuji adalah bahwa itu baik. Hal ini akan dikaitkan dengan kinerja yang unggul. Dalam penelitian mereka, Hendry dan Pettigrew berkonsentrasi pada pemetaan konteks, mengidentifikasi konteks dalam (organisasi) dan konteks luar (lingkungan yang lebih luas) dan mengeksplorasi bagaimana MSDM beradaptasi terhadap perubahan dalam konteks daripada menganalisis hubungan apa pun dengan kinerja. 
Di AS, perhatian lebih terfokus pada mengklasifikasikan jenis strategi SDM, sering mengacu pada model strategi perusahaan yang ada. Salah satu contoh yang sering dikutip telah disajikan oleh Miles dan Snow (1984), membangun karya mereka sebelumnya tentang strategi dan struktur. Mereka mengusulkan bahwa masing-masing jenis strategis perusahaan perlu mengadopsi serangkaian kebijakan SDM yang berbeda dan mereka cukup tepat tentang beberapa variasi. Lagi-lagi hipotesisnya adalah bahwa perusahaan yang memiliki kesesuain antara strategi bisnis, struktur, dan kebijakan serta praktik SDM akan memiliki kinerja yang unggul. Alasan yang sama ada di balik karya Schuler dan Jackson (1987) yang menguraikan tiga strategi MSDM terkait dengan Porter (1980) tiga strategi kompetitif umum.

Ada beberapa penulis lain yang karyanya berada dalam fokus luas pada strategi ini. Mereka sangat membantu dalam mengidentifikasi pengaruh pada strategi dan kadangkadang dalam menentukan tipe MSDM. Tetapi mereka sering menyederhanakan dalam mengkarakterisasi MSDM, biasanya mengidentifikasi sekitar empat bidang kegiatan yang luas seperti seleksi, pelatihan dan pengembangan, penghargaan dan karier. Sementara implikasinya adalah perusahaan yang mencapai antara strategi bisnis dan strategi MSDM akan memiliki kinerja yang unggul, mereka lemah dalam menentukan proses di mana MSDM terkait dengan kinerja. Akhirnya, mereka umumnya mengadopsi pandangan yang terbatas tentang kinerja, mendefinisikannya sebagian besar dalam istilah finansial.

Ini ditetapkan untuk menggambarkan medan secara komprehensif. Dua yang paling terkenal adalah yang disajikan oleh Beer dan rekan-rekannya dari Harvard (Beer et al. 1985) dan oleh Kochan, Katz dan McKersie (1986) dari MIT. Dalam kedua kasus, ada upaya untuk menangkap bidang luas dan untuk mengatasi beberapa hubungan timbal balik. Untuk Bir $d k k$. ini berarti mendaftar empat bidang kebijakan dan praktik MSDM yang luas dan empat hasil utama. Untuk Kochan dan rekannya itu memerlukan pendekatan sistem, menggambarkan hubungan timbal balik antar tingkat. Keduanya pada dasarnya deskriptif, memetakan bidang dan mengklasifikasikan input dan output. Keduanya dapat dikembangkan menjadi teori, tetapi hanya pada tingkat spesifikasi yang sangat umum. Kekuatan dan kelemahan dalam hal ini adalah penekanan pada keterbukaan pendekatan sistem yang dapat secara akurat menangkap elemen realitas tetapi gagal untuk menawarkan spesialisasi tertentu.

Dengan memberikan peta konseptual lapangan, model-model ini memang memberikan klasifikasi yang luas dari konten MSDM dan berbagai hasil. Keduanya berguna dalam mengadopsi pendekatan pemangku kepentingan dan dalam mengidentifikasi berbagai hasil yang menarik bagi berbagai pemangku kepentingan. Namun, mereka pada dasarnya 
adalah model hubungan karyawan yang peduli dengan peran manajer dalam menyeimbangkan kepentingan yang bersaing, dalam menyoroti ruang lingkup pilihan dan dalam mengidentifikasi beberapa pengaruh pada pilihan. Meskipun preferensi tersirat pada bagian dari penulis mereka, dengan menentukan berbagai pilihan dan tidak merekomendasikan pendekatan spesifik, mereka sebagian besar non-preskriptif. Oleh karena itu mereka tidak memberikan fokus yang jelas untuk uji hubungan antara MSDM dan kinerja.

Model atau teori jenis ini lebih bersifat preskriptif dalam pendekatan mereka, mencerminkan pandangan apakah ada cukup pengetahuan yang ada untuk memberikan dasar bagi praktik terbaik yang ditentukan atau bahwa serangkaian nilai menunjukkan praktik terbaik. Seringkali kedua perspektif ini menjadi terkendali. Salah satu contoh paling terkenal dari pendekatan ini adalah pekerjaan Walton tentang kontrol dan komitmen (Walton, 1985). Dalam menyajikan perbedaan antara dua pendekatan dalam pengelolaan sumber daya manusia, ia mengikuti McGregor (1960) sekitar dua puluh lima tahun sebelumnya dengan mengatakan ini adalah satu-satunya tipe ideal tetapi dalam praktiknya jika anda ingin. Dia meresepkan strategi komitmen sebagai dasar khas untuk MSDM. Analisis umum yang sama dapat ditemukan dalam karya Lawler $(1986,1992)$, meskipun ia menggunakan bahasa keterlibatan daripada MSDM. Baru-baru ini, karya Pfeffer (1994) telah menarik banyak perhatian. Dia mendaftar enam belas praktik MSDM (kemudian diubah menjadi tiga belas (Pfeffer, 1995) dengan alasan bahwa jumlah yang tepat dan mungkin sifat yang tepat dari praktik tersebut tidak diketahui secara jelas atau tidak terlalu penting) yang ia dukung dengan alasan bahwa efek positifnya sekarang mapan

(Guest, 1987) telah berusaha menangkap beberapa semangat pendekatan ini dengan berusaha menyajikannya dalam kerangka kerja yang koheren, menetapkan beberapa tautan sehingga model yang dihasilkan setidaknya dapat diuji - dan mungkin disangkal. Hipotesis sentral adalah bahwa jika seperangkat praktik MSDM yang terintegrasi diterapkan dengan tujuan untuk mencapai tujuan normatif dari komitmen yang tinggi terhadap organisasi ditambah dengan kualitas dan fleksibilitas yang tinggi, maka kinerja pekerja yang lebih tinggi akan dihasilkan. Asumsinya adalah bahwa ini akan berdampak positif pada kinerja organisasi. Tidak seperti pendekatan lain, perspektif normatif ini berpendapat bahwa praktik spesifik dan tujuan MSDM tertentu akan selalu lebih unggul.

Ada sejumlah masalah dengan pandangan MSDM ini. Salah satunya adalah ia berfokus terutama pada karakteristik internal MSDM dengan mengorbankan isu-isu strategis yang lebih luas. Dalam melakukannya, dan dalam mengadvokasi serangkaian praktik terbaik 
sambil mengabaikan berbagai tekanan dan strategi bisnis konsekuen, itu mengambil risiko yang cukup besar dalam menyiratkan 'satu cara terbaik'. Masalah kedua adalah bahwa, meskipun tujuan MSDM dapat didefinisikan dengan baik, daftar praktik MSDM yang terkait masih jauh dari jelas (untuk garis besar variabel yang termasuk dalam berbagai studi, lihat Dyer dan Reeves (1995) dan Becker dan Gerhart (1996)) dan menunggu baik spesifikasi teoretis yang jelas atau basis empiris yang lebih kuat.

Masing-masing dari tiga pendekatan yang diuraikan memiliki semacam landasan teori baik dalam strategi kontingensi / bisnis, teori sistem atau OB / teori motivasi. Masing-masing menyiratkan tingkat analisis yang agak berbeda. Hanya yang kedua dan lebih khusus yang ketiga mulai menentukan dimensi kebijakan dan praktik MSDM dengan cara apa pun yang berpotensi membantu untuk pengukuran dan bahkan mereka tidak benar-benar tepat. Singkatnya, kita masih kekurangan landasan teori yang koheren untuk mengklasifikasikan kebijakan dan praktik MSDM, masalah yang menjadi lebih jelas ketika kita mulai melihat penelitian empiris.

\section{Kinerja}

Tidak ada teori umum tentang kinerja . Namun, kami memiliki sejumlah pendekatan dan model, sering dibangun di atas perspektif disiplin ilmu tertentu, seperti ekonomi, psikologi atau manajemen produksi, yang membantu kami untuk memahami dan mengklasifikasikan aspek kinerja. Ini bukan tugas yang mudah. Dalam bidang Perilaku Organisasi, pengukuran kinerja sering digambarkan sebagai masalah kriteria. Kita mungkin tergoda untuk memperluas ini ke studi MSDM. Kita dapat mulai memahami kinerja dengan menyoroti sejumlah perbedaan. Pertama, kita bisa fokus pada masalah yang menyangkut konten kinerja. Kedua, kita dapat mempertimbangkan jenis data. Ketiga, kita dapat mempertimbangkan keterkaitan dalam pandangan yang luas tentang kinerja dan dengan demikian mulai mengeksplorasi hubungan sebab akibat antara MSDM dan kinerja.

Masalah sifat data tumpang tindih dengan pertanyaan tentang jenis data apa yang menarik. Siapa pemangku kepentingan kinerja - dan apakah ini sama dengan hasil? Dapat diperdebatkan, kinerja adalah kriteria yang didominasi perusahaan sementara hasilnya berpotensi jauh lebih luas. Mereka mungkin termasuk masalah lingkungan, kepuasan kerja, kontribusi untuk kegiatan masyarakat dan sebagainya. Ada risiko, dalam melihat kriteria kinerja yang ditentukan secara organisasi, bahwa beberapa masalah ini diabaikan. Dapat dikatakan bahwa, jika kekhawatiran sempit untuk kinerja perusahaan, ini tidak masalah. Di 
sisi lain, jika teori implisit MSDM adalah bahwa hasil dicapai melalui pemanfaatan yang efektif, berlawanan dengan eksploitasi, sumber daya manusia, mereka mungkin sangat penting. Namun, bahkan ini mungkin tidak cukup, karena kita tahu dari banyak penelitian bahwa hanya ada hubungan yang sangat lemah antara kinerja dan kepuasan kerja (Staw, 1986). Juga, ada beberapa indikasi bahwa perusahaan yang sangat sukses mungkin bukan di mana pekerja lebih suka bekerja (Levering et al., 1984; untuk diskusi yang lebih lengkap, lihat Tamu, 1992).

Berdasarkan analisis pemangku kepentingan, salah satu istilah yang kadang-kadang digunakan dalam diskusi tentang MSDM adalah konsep 'kartu skor berimbang '. Ini hanya menyiratkan bahwa tidak cukup untuk berkonsentrasi pada satu pandangan kinerja dengan mengorbankan yang lain. Seperti dalam teori sistem sosial-teknis lama, perlu untuk mengoptimalkan setiap dimensi daripada memaksimalkan satu dengan mengorbankan yang lain. Biasanya, item pada kartu skor adalah item yang penting bagi konstituensi keuangan, pelanggan, dan karyawan. Jika kita menerima ini, kita perlu beberapa kriteria kinerja, suatu poin yang disorot dalam model deskriptif MSDM dan tersirat dalam seluruh gagasan untuk mengambil manajemen sumber daya manusia dengan serius. Ini berarti kita harus berhati-hati dalam menekankan salah satu kepentingan ini dengan mengorbankan kepentingan yang lain, terutama jika kita menggunakan tindakan satu kali.

Pada dasarnya ada tiga jenis data kinerja yang tersedia (Locke dan Latham, 1990); yaitu ukuran output barang dan jasa, yang mungkin kuantitatif (unit diproduksi, pelanggan dilayani) atau kualitatif (jumlah kesalahan, keluhan pelanggan); ukuran waktu, termasuk keterlambatan, ketidakhadiran, kehilangan waktu kerja, kegagalan memenuhi tenggat waktu); dan indikator keuangan, yang mencakup sejumlah besar kemungkinan. Ini mungkin saling terkait; dengan demikian ketiadaan mengurangi tingkat unit produksi yang mengurangi laba.

Di mana data kuantitatif tidak tersedia, kami mungkin ingin melakukan tindakan perilaku. Idealnya, kami mengamati orang-orang di tempat kerja, memperhatikan apakah mereka mendekati pelanggan dan menawarkan bantuan, atau mencatat apakah mereka mengamati prosedur keselamatan. Jika gagal, kita dapat memperoleh laporan baik dari 'pengamat ', seperti atasan atau rekan atau bawahan, atau dari orang yang diteliti.

Perspektif yang sama dapat diadopsi untuk data kinerja yang menarik bagi pemangku kepentingan lain, misalnya mereka yang peduli dengan lingkungan. Pengukuran menjadi lebih kompleks ketika diterapkan pada karyawan, karena kita perlu menambahkan evaluasi 
subjektif. Poin penting adalah bahwa mereka harus dikumpulkan secara sistematis, mungkin melalui mekanisme seperti survei sikap.

Tentu saja, kerangka kerja analitik untuk mempertimbangkan rentang data kinerja tidak dapat menyembunyikan bias dan preferensi - mungkin untuk langkah-langkah keuangan juga tidak dapat mencegah interpretasi subjektif dan menimbang informasi. Poin sederhananya adalah bahwa sebagai peneliti, kita mungkin harus menyadari kisaran jenis data yang mungkin dikumpulkan untuk menunjukkan kinerja. Ada juga penilaian implisit tentang prioritas yang disukai, dimulai dengan langkah-langkah 'sulit', diikuti oleh perilaku, diikuti oleh laporan atau peringkat. Tentu saja kami mungkin ingin menyeimbangkan pandangan post-modernis bahwa semua ukuran kinerja adalah konstruksi sosial, terbuka untuk berbagai interpretasi, terhadap pengakuan bahwa memperluas definisi kinerja dan memberikan bukti tentang kaitan antara MSDM dan kinerja mungkin merupakan satu dari cara yang lebih efektif untuk memastikan bahwa pembuat kebijakan menanggapi masalah SDM dengan serius.

Data sendiri tidak banyak memberi tahu kami. Kami membutuhkan beberapa dasar untuk perbandingan, baik cross-sectional atau longitudinal; kita juga perlu memahami hubungan antara tipe data kinerja. Seperti yang telah disebutkan, ketidakhadiran dapat mengurangi produksi yang dapat memengaruhi laba. Banyak hubungan jenis ini dapat dibuat. Jika kita bergerak ke arah model perilaku, maka kita mungkin ingin menghubungkan persepsi karyawan dengan perilaku mereka, dengan hasil kinerja tingkat individu atau kelompok yang mempengaruhi kinerja unit dan dengan demikian dengan laba perusahaan. Untuk memahami, sebagai kebalikan dari pengukuran kinerja, kita perlu membuat keterkaitan ini. Mungkin ada hubungan antara praktik MSDM dan laba perusahaan, tetapi, tanpa beberapa hubungan, kita tidak akan tahu mengapa; kami tidak punya teori. Ini menyiratkan bahwa kita memerlukan serangkaian jenis ukuran kinerja pada tingkat individu, kelompok, unit, dan perusahaan untuk mulai membangun keterkaitan ini. Sampai saat ini, MSDM telah lemah di bidang ini.

\section{HASIL DAN PEMBAHASAN}

\section{Teori Tentang Hubungan Antara MSDM dan Kinerja}

Baik strategi maupun model deskriptif tidak memberikan banyak wawasan tentang bagaimana kebijakan dan praktik MSDM diterjemahkan menjadi kinerja tinggi. Mereka memandang MSDM sebagai satu-satunya bagian dari penjelasan untuk kinerja tinggi dan 
menyarankan bahwa, ketika berbagai sub-sistem termasuk sub-sistem MSDM diselaraskan dan saling mendukung, kinerja yang unggul mungkin terjadi. Orang yang tepat akan berada di tempat yang tepat melakukan hal yang benar. Ini adalah model pengorganisasian manajerial, khususnya dalam versi strategis. Model deskriptif, karena akar hubungan karyawan mereka, memberikan bobot lebih pada peran aktif karyawan, tetapi terutama dalam negosiasi order.

Sebaliknya, pendekatan normatif berakar kuat dalam psikologi organisasi dan dibangun di atas teori perilaku yang lebih rendah dan lebih spesifik. Asumsinya adalah bahwa praktik MSDM yang 'tepat' memanfaatkan motivasi dan komitmen karyawan. Faktorfaktor yang membentuk praktik 'sesuai' berasal dari teori spesifik tentang komitmen organisasi, desain pekerjaan, penetapan tujuan, dan sebagainya. Fitur utama dari pendekatan ini adalah bahwa MSDM memberikan integrasi yang koheren dari teori-teori perilaku ini dan bahwa mereka menguraikan hubungan antara praktik dan kinerja.

Dimungkinkan untuk mengembangkan teori penyelarasan, menjelaskan serangkaian keterkaitan dengan kinerja, baik pada tingkat strategi yang lebih luas dan pada tingkat praktik SDM yang lebih spesifik. Dimulai dengan yang terakhir, teori motivasi harapan memberikan satu dasar yang mungkin untuk mengembangkan alasan yang lebih koheren tentang hubungan antara praktik MSDM dan kinerja. Pendekatan yang dekat dengan teori ekspektasi diadopsi oleh MacDufŽe (1995). Seperti yang ia katakan, Praktek sumber daya manusia yang inovatif cenderung berkontribusi pada peningkatan kinerja ekonomi hanya ketika tiga kondisi terpenuhi: ketika karyawan memiliki pengetahuan dan keterampilan yang kurang dimiliki manajer; ketika karyawan termotivasi untuk menerapkan keterampilan dan pengetahuan ini melalui upaya diskresioner; dan ketika strategi bisnis atau produksi perusahaan hanya dapat dicapai ketika karyawan berkontribusi dalam upaya diskresi tersebut. Saya akan berpendapat bahwa ketiga kondisi tersebut harus dipenuhi agar praktik SDM dapat berkontribusi pada kinerja (MacDufe, 1995:199).

Meskipun teori ekspektasi terutama berkaitan dengan motivasi, itu juga merupakan teori tentang hubungan antara motivasi dan kinerja. Secara khusus, ini mengusulkan bahwa kinerja tinggi, pada tingkat individu, tergantung pada motivasi tinggi ditambah kepemilikan keterampilan dan kemampuan yang diperlukan dan peran yang tepat dan pemahaman peran itu. Ini adalah langkah singkat untuk menentukan praktik MSDM yang mendorong keterampilan dan kemampuan tinggi, misalnya seleksi yang cermat dan investasi yang tinggi dalam pelatihan; motivasi tinggi, misalnya keterlibatan karyawan dan kemungkinan 
pembayaran terkait kinerja; dan struktur peran yang tepat dan persepsi peran, misalnya desain pekerjaan dan komunikasi serta umpan balik yang luas. Ini diilustrasikan pada Gambar 1. Oleh karena itu kami memiliki teori yang menghubungkan praktik MSDM dengan proses yang memfasilitasi kinerja individu yang tinggi; lebih jauh lagi, ini adalah sebuah teori yang cocok dengan orientasi individualistik dari pendekatan normatif untuk MSDM.

Sebelum menjadi terlalu antusias tentang teori yang mengaitkan praktik dan kinerja MSDM, kita harus ingat bahwa setiap analisis pengaruh terhadap laba perusahaan atau output pabrik atau bahkan tingkat ketidakhadiran dengan cepat mengarah pada kesimpulan bahwa faktor-faktor selain MSDM terlibat. Oleh karena itu, kita perlu memiliki teori tentang kapan sumber daya manusia lebih penting; misalnya, faktor manusia mungkin lebih penting di sektor jasa. Kita juga memerlukan teori tentang seberapa besar perbedaan dapat dijelaskan oleh faktor manusia. Apakah ada pengaruh yang signifikan secara statistik, misalnya ketika regresi mengungkapkan bahwa MSDM menjelaskan 2 persen dari varians kinerja, hasil yang baik? Atau haruskah kita, seperti yang disarankan oleh Becker dan Gerhart (1996), memberi lebih banyak perhatian pada efek ukuran daripada pada signifikansi statistik? Bisakah kita, sebagaimana Huselid (1995) yang baru-baru ini dicoba, memberi harga pada manfaat MSDM yang baik? Untuk ini, kita membutuhkan kerangka kerja konseptual yang agak luas serta dasar yang diterima untuk menilai apa yang merupakan hasil penting.

Pilihan Sosialisasi

Pelatihan dan pengembangan

Program peningkatan kualitas

Status tunggal

Keamanan kerja

Promosi internal

Sistem penghargaan individual

Komunikasi

Keterlibatan karyawan

Kerja tim

Desain pekerjaan
Keterampilan dan Kemampuan

(Kualitas)

Usaha / Motivasi

(Komitmen)

Struktur Peran dan Persepsi

(Fleksibilitas)

\section{Gambar 1. Menghubungkan Praktik MSDM dan Hasil MSDM}

Beralih ke kerangka kerja yang mungkin lebih luas yang menghubungkan MSDM dan hasil, titik awal harus menjadi pengakuan, seperti disebutkan di atas, bahwa fitur khas MSDM adalah asumsi bahwa peningkatan kinerja dicapai melalui orang-orang dalam organisasi. Setiap teori hubungan harus secara eksplisit membangun ini. Sebuah model yang menggambarkan jenis hubungan yang mungkin dieksplorasi, meskipun menggunakan 
kategori arbitrer untuk strategi MSDM dan praktik-praktik MSDM, disajikan pada Gambar 2. Nilai utamanya dalam konteks saat ini terletak pada menyoroti berbagai hasil terkait yang perlu dipertimbangkan dalam model apa pun yang berupaya memahami dampak faktor 'manusia' dalam manajemen sumber daya manusia.

Gambar 2 mengakui peran untuk konteks dan strategi eksternal tetapi menunjukkan, pada intinya, bahwa praktik MSDM harus dirancang untuk mengarah pada hasil MSDM dari komitmen karyawan yang tinggi, staf berkualitas tinggi dan staf yang sangat fleksibel. Komitmen tinggi akan dinilai menggunakan langkah-langkah standar dan berdasarkan definisi yang dipopulerkan oleh Mowday, Porter dan Steers (1982) identifikasi dengan nilai-nilai organisasi, keinginan untuk menjadi bagian dari organisasi dan keinginan untuk melakukan sesuatu untuk organisasi. Staf berkualitas tinggi mengacu pada kemampuan dan pengetahuan dan keterampilan staf. Fleksibilitas mengacu pada fleksibilitas fungsional daripada numerik. Praktik spesifik yang membantu untuk mencapai hasil ini diilustrasikan pada Gambar 1. Menurut model, hanya ketika ketiga hasil MSDM tercapai kita dapat mengharapkan perubahan perilaku dan kinerja yang lebih tinggi.

\begin{tabular}{|c|c|c|c|c|c|}
\hline Strategi MSDM & Praktek MSDM & Hasil MSDM & Hasil Tingkah laku & Hasil Kinerja & Hasil Finasial \\
\hline Diferensiasi & Seleksi & Komitmen & Upaya/motivasi & Produktivitas, kualitas & Keuntungan \\
\hline (Inovasi) & Pelatihan & & Motivasi & dan inovasi tinggi & \\
\hline Fokus & Penilaian & & Kerja sama & & \\
\hline \multicolumn{6}{|l|}{ (kualitas) } \\
\hline Biaya & Hadiah & Kualitas & Keterlibatan & Ketidakhadiran rendah & Pengembalian \\
\hline \multirow[t]{5}{*}{ (Pengurangan Biaya } & Desain pekerjaan & & & Konflik pergantian buruh rendah & Investasi \\
\hline & Keterlibatan & Fleksibilitas & Kekeluargaan organisasi & Keluhan pelanggan rendah & \\
\hline & & & & Pergantian buruh kecil & \\
\hline & Status dan & & & & \\
\hline & Keamanan & & & & \\
\hline & & & & & \\
\hline
\end{tabular}

Gambar 2. Menghubungkan MSDM dan Kinerja

Mengingat kerangka kerja pada Gambar 2, penting untuk mengukur hasil MSDM untuk memahami bagaimana dampak MSDM terhadap kinerja. Ketika kita melanjutkan tahap-tahap yang tersisa dalam model, kita akan mengharapkan dampak MSDM menjadi semakin lemah ketika faktor-faktor lain ikut campur. Model pada Gambar 2 memisahkan perubahan dalam perilaku, kinerja dan hasil keuangan. Penting untuk dicatat bahwa di bawah judul luas kinerja ada perbedaan lebih lanjut yang dapat dibuat, misalnya antara kinerja dan efektivitas, yang merupakan penilaian subjektif dari kinerja dan mungkin produktivitas; dan antara kinerja, yang berkaitan dengan output, dan produktivitas, yang berkaitan dengan rasio 
input-output. Karena efektivitas dapat dianggap sangat berbeda oleh berbagai pemangku kepentingan, akan diinginkan jika memungkinkan untuk memasukkan langkah-langkah efektivitas tambahan bersama dengan ukuran hasil yang lebih objektif.

\section{Bukti Empiris tentang MSDM dan Kinerja}

Sekarang ada semakin banyak studi yang membuat upaya serius untuk menghubungkan MSDM dan kinerja. (Ada, tentu saja, ratusan yang memeriksa aspek-aspek tertentu dari MSDM dan kinerja.) Mereka tidak semua melihat hal yang sama sehingga mereka secara kumulatif hanya dalam pengertian yang sangat umum. Salah satu upaya menarik untuk mengidentifikasi berbagai pendekatan yang mungkin telah diperoleh dari karya Venkatraman (1989) yang tujuannya adalah untuk mengklasifikasikan berbagai jenis 'kecocokan dalam penelitian tentang strategi. Baru-baru ini, pendekatannya telah sedikit diadaptasi oleh Sivasubramaniam dan Kroeck (1995) untuk mengklasifikasikan berbagai perspektif tentang MSDM. Konsep 'kecocokan' atau 'integrasi' adalah inti dari banyak upaya untuk berteori tentang MSDM sehingga ini tampaknya cara yang menarik untuk mencoba melanjutkan. Pada dasarnya, mereka menyarankan bahwa berbagai jenis MSDM tidak dapat dipesan sepanjang dua dimensi yaitu kecocokan Internal -Eksternal dan Kriteria spesifik atau Kriteria bebas. Ini memberikan empat kemungkinan utama, meskipun satu lagi dibagi. Saya telah membuat banyak perubahan pada deskripsi yang digunakan dalam kedua makalah sebelumnya:

Cocok sebagai interaksi strategis berupaya untuk menghubungkan praktik SDM dengan konteks eksternal dan mencerminkan standar pendekatan strategis. Poin kuncinya adalah bahwa ada pilihan tentang bagaimana menanggapi dan berinteraksi dengan lingkungan. Setelah pilihan itu dibuat, maka strategi dan praktik SDM harus mencocokkannya. Hipotesisnya adalah organisasi-organisasi dengan respons yang sesuai dan kecocokan yang tepat akan melaporkan kinerja superior. Tes khas ini adalah untuk menguji hubungan antara jenis strategi Miles dan Snow dan praktik MSDM yang terkait dengan masing-masing dan menghubungkannya dengan beberapa ukuran diukur terutama melalui kriteria keuangan.

Cocok sebagai kemungkinan mencerminkan pendekatan kontingensi tradisional, menunjukkan bahwa organisasi - organisasi yang kebijakan dan praktik SDM-nya lebih responsif terhadap faktor-faktor eksternal akan melaporkan kinerja yang unggul. Faktorfaktor eksternal ini dapat mencakup sifat pasar, perubahan legislatif atau fitur-fitur sektor 
spesifik. Pendekatan ini cenderung mengasumsikan bahwa respons tertentu akan selalu lebih unggul, tetapi tidak menentukan jenis respons atau kelas respons apa pun, meskipun tidak ada alasan mengapa hal ini tidak dapat dilakukan.

\begin{tabular}{|l|l|l|}
\hline & Kriteria spesifik & Kriteria bebas \\
\hline Internal & $\begin{array}{l}\text { Kecocokan dengan serangkaian praktek } \\
\text { ideal }\end{array}$ & $\begin{array}{l}\text { Kecocokan sebagai gestalt } \\
\text { Kecocokan sebagai bundel }\end{array}$ \\
\hline eksternal & Kecocokan sebagai interaksi strategis & Kecocokan sebagai kemungkinan \\
\hline
\end{tabular}

\section{Gambar 3. Bentuk kecocokan MSDM}

Cocok sebagai serangkaian praktik ideal menyiratkan bahwa ada serangkaian 'praktik SDM terbaik' - Daftar Pfeffer (1994) mungkin menjadi salah satu contoh - dan yang menjadi perhatian adalah seberapa dekat organisasi dengan serangkaian praktik SDM yang ideal. Hipotesisnya adalah mereka yang lebih dekat dengan tipe ideal akan melaporkan kinerja yang lebih tinggi.

Kecocokan sebagai gestalt menyiratkan bahwa kunci MSDM yang efektif terletak pada menemukan kombinasi praktik yang tepat. Selain itu, diasumsikan bahwa jumlah lebih besar daripada bagian-bagian. Mungkin kombinasi sinergis dari semua praktik atau mungkin 'arsitektur ' atau budaya tertentu yang mengikat mereka bersama. Ini kadang-kadang dilihat sebagai elemen yang tidak dapat direplikasi yang dapat memberikan organisasi sumber keunggulan kompetitif berbasis sumber daya manusia. Salah satu implikasi dari model ini adalah bahwa studi aspek spesifik MSDM seperti gaji atau pelatihan dapat memberikan gambaran yang menyimpang. Kecuali jika kontrol yang sangat hati-hati digunakan untuk memperhitungkan semua praktik MSDM lainnya, ada kemungkinan bahwa hasilnya mungkin melebih-lebihkan pengaruh praktik spesifik dengan mengambil dampak gabungan dari rangkaian praktik tersebut. Pada prinsipnya, pendekatan ini berbeda dari konsep tipe cocok ideal yang tidak menentukan dimensi praktik MSDM; dan dari kedua tipe ideal dan pendekatan 'bundel ' yang diuraikan di bawah ini sebagai multiplikasi dan bukan aditif. Implikasinya, jika satu aspek kunci hilang, gestalt mungkin tidak ada.

Sesuai sebagai 'bundel 'menyiratkan adanya pola atau konfigurasi khusus - yang kadang-kadang disebut 'bundel ' - dari praktik dan kuncinya adalah untuk menentukan mana yang paling efektif. Pada prinsipnya mungkin ada sejumlah kemungkinan kombinasi atau konfigurasi praktik yang akan menghasilkan kinerja tinggi; misalnya, beberapa organisasi mungkin menekankan keamanan kerja sebagai blok bangunan; yang lain lebih suka pelatihan dan pengembangan. Untuk menguji ini, kuncinya adalah untuk melihat bukan pada jumlah total praktik MSDM tetapi untuk mengambil mereka yang mengadopsi di atas jumlah 
tertentu, mungkin median, selama inti yang berbeda ada. Di dalam masing-masing bundel ada kemungkinan substitusi; misalnya, secara statistik, mungkin ada sedikit yang bisa diperoleh dengan melaporkan kedua penggunaan pratinjau pekerjaan yang realistis dan tes psikometri dalam seleksi karena keduanya sama-sama menunjukkan seleksi yang cermat. Meski secara prinsip pendekatan ini memungkinkan kesetaraan, atau substitusi, dalam praktiknya kluster tertentu dapat muncul secara konsisten, menunjukkan kisaran terbatas kombinasi efektif.

Kebanyakan studi MSDM dan kinerja yang dilaporkan dapat diklasifikasikan dalam satu atau yang lain dari kategori ini. Namun, kami agak jauh dari melihat semua kemungkinan diuji. Memang, Delery dan Doty (1996) berpendapat bahwa sebenarnya ada tiga pendekatan utama - pendekatan kontingensi strategis, pendekatan praktik terbaik dan pendekatan konfigurasi, yang mewakili teori eksternal, internal, dan sistem - dan bahwa ini memberikan persaingan yang kaya perspektif teoretis. Karena ada sangat sedikit penelitian tentang pendekatan kontingensi murni dan, terlepas dari beberapa studi kasus tertentu, sedikit eksplorasi perspektif 'gestalt', bagian selanjutnya berkonsentrasi pada tiga pendekatan utama ini.

Kecocokan Eksternal: MSDM sebagai integrasi strategis Ada beberapa dukungan untuk pendekatan ini. Huselid (1995) telah menemukan bahwa organisasi yang menghubungkan praktik MSDM dengan strategi melaporkan hasil kinerja keuangan yang lebih tinggi. Delery dan Doty (1996) menemukan dukungan sederhana untuk kecocokan dengan tipologi Miles dan Snow. Youndt et al. (1996) menemukan dukungan untuk tipe ini dalam sampel sembilan puluh tujuh pabrik, terutama terkait antara praktik MSDM kinerja tinggi dan strategi kualitas. MacDufe (1995), sebaliknya, secara eksplisit menolak hipotesis ini, mengklaim bahwa dalam studi internasional tentang pabrik mobil ia tidak menemukan bukti bahwa 'kecocokan ' dari praktik MSDM yang tepat untuk produksi massal dapat bersaing dengan produksi yang fleksibel.

Kecocokan Internal: MSDM sebagai serangkaian praktik ideal. Ini adalah yang paling banyak diuji dan jenis kecocokan yang paling didukung. Hampir setiap penelitian, termasuk yang sudah dikutip tetapi juga yang dilaporkan oleh Huselid dan rekan-rekannya (Huselid, 1995; Huselid, Jackson dan Schuler, 1995; Delaney dan Huselid, 1996), oleh Arthur (1994), Ichniowski, Shaw dan Prennushi (1994)) dan MacDuf e (1995) mendukung jenis ini. Pada dasarnya, apa yang mereka semua tunjukkan, baik lintas industri atau dalam sektor tertentu, adalah bahwa semakin banyak praktik MSDM kinerja tinggi yang digunakan, semakin baik kinerjanya seperti yang ditunjukkan oleh produktivitas, pergantian tenaga kerja 
atau indikator keuangan. Di mana berbagai jenis kecocokan dibandingkan, ini selalu yang menerima dukungan terkuat. Pengecualian utama untuk pola umum ini, sampai saat ini, adalah studi oleh Youndt di al. (1996) yangMenemukan bahwa 'kecocokan' antara praktik MSDM kinerja tinggi dan strategi kualitas memberikan hasil terbaik.

Keocockan konfigurasi: MSDM sebagai bundel Huselid dan Becker (1995), dalam sebuah studi panel, telah memberikan tes parsial ini dengan memeriksa dampak dari tiga faktor terpisah yang muncul dari analisis faktor mereka dari daftar praktik MSDM. Dalam sebuah penelitian yang menggunakan ukuran subjektif dari kinerja organisasi, Delaney dan Huselid (1996) gagal menemukan dampak positif untuk kombinasi tertentu dari praktik yang bertentangan dengan jumlah total praktik MSDM. Namun Delery dan Doty (1996) menemukan beberapa dukungan untuk pendekatan konfigurasi dalam studi mereka di sektor perbankan.

Menyatukan hasil ini, ada dukungan empiris untuk masing-masing dari tiga pendekatan utama untuk MSDM dan kinerja tetapi secara konsisten lebih kuat mendukung untuk model kecocokan internal dengan pandangannya bahwa organisasi-organisasi yang menggunakan lebih banyak praktik MSDM kinerja tinggi melaporkan kinerja yang lebih tinggi. Pendekatan umum yang diwakili oleh aliran penelitian ini cukup menggembirakan untuk menyarankan bahwa hal itu dilanjutkan dan ditingkatkan. Tidak ada keraguan bahwa itu menarik banyak minat penelitian di Amerika Utara. Diharapkan dapat melakukan hal yang sama di Eropa. Namun, dalam mengedepankannya, kita perlu mewaspadai kekurangan dan dengan demikian kembali ke masalah teori.

\section{KESIMPULAN}

Masalah pertama adalah kurangnya teori tentang sifat praktik MSDM. Seperti yang saya katakan di tempat lain (Tamu, 1987), bukanlah kehadiran seleksi atau pelatihan tetapi pendekatan khusus untuk seleksi atau pelatihan yang penting. Ini adalah penggunaan praktik MSDM kinerja tinggi atau komitmen tinggi. Ada sedikit konsensus tentang apa ini dan sedikit minat hingga saat ini dalam mengembangkan teori tentang apa yang mungkin bagi mereka. Saya akan mengusulkan bahwa kita membangun sesuatu seperti teori ekspektasi, dengan cara yang diuraikan di atas, untuk memberikan alasan yang masuk akal untuk praktik-praktik ini. Seperti yang ditunjukkan MacDufe (1995), teori ekspektasi, atau beberapa variasi darinya, juga dapat menunjuk ke sejumlah konfigurasi tergantung pada penyajian yang disukai dan mungkin mengindikasikan kapan gaji terkait-kinerja dapat 
dianggap sebagai praktik kinerja tinggi. Alternatifnya adalah dengan mengadopsi pendekatan statistik dan untuk melihat apa yang muncul dari analisis faktor atau beberapa variasi (untuk contohnya, lihat Wood and Albanese, 1995). Dalam membangun serangkaian praktik terbaik, kita juga harus berhati-hati untuk memperhitungkan perbedaan budaya, misalnya dalam praktik yang terkait dengan pelatihan, keamanan pekerjaan, atau serikat pekerja. Akhirnya, dalam mengumpulkan informasi tentang kebijakan dan praktik MSDM kinerja tinggi, kita perlu berhati-hati tentang asumsi validitas yang mendasari penggunaan data yang dikumpulkan di kantor pusat sebagai dasar untuk pernyataan di seluruh perusahaan tentang praktik SDM di tempat yang mungkin merupakan lokasi multi-pabrik.

Kekhawatiran kedua adalah meningkatkan ukuran kinerja kami. Memang, kinerja mungkin istilah yang salah. Mungkin lebih masuk akal untuk menggunakan istilah 'hasil'. Satu argumen mungkin bahwa filosofi unitaris yang menggarisbawahi MSDM menyiratkan bahwa karyawan berbagi kepedulian dengan pemegang saham untuk laba. Namun, itu tidak bijaksana untuk mnerima asumsi ini. Yang kami butuhkan adalah hasil yang mencerminkan konsep kartu skor seimbang. Gagasan keseimbangan, seperti konsep optimalisasi sistem sosio-teknis, menyiratkan bahwa kompromi terkadang diperlukan. Studi tingkat pabrik yang dilaporkan oleh Arthur (1994), MacDufŽ (1995) dan Guest and Hoque (1994) mengukur produktivitas dan kualitas, tetapi studi yang dilakukan oleh Huselid (1995) dan lainnya yang menggunakan langkah-langkah tingkat perusahaan sangat menekankan kriteria keuangan. Meskipun terdapat indikator keuangan yang menarik untuk setiap upaya meyakinkan manajer senior tentang dampak MSDM, kita perlu menggunakan rentang ukuran hasil yang lebih besar jika hanya untuk memahami bagaimana dan mengapa MSDM berdampak pada hasil keuangan.

Penelitian oleh Guest dan Hoque menimbulkan pertanyaan tentang kriteria yang kontradiktif. Pendirian mereka dikategorikan sebagai 'jelek ', dengan strategi yang disengaja dari serapan rendah praktik MSDM kinerja tinggi, melaporkan hasil kinerja sebaik kategori lainnya tetapi memiliki hasil SDM yang lebih buruk dan hasil hubungan karyawan. Perusahaan mendapatkan hasil yang baik tetapi bukan tempat yang menarik untuk bekerja. Studi lain tidak memperhitungkan kriteria hasil yang kontradiktif.

Hanya ketika kita telah membuat kemajuan dalam mengukur variabel independen dan dependen kita dapat mulai memberikan perhatian penuh pada cara di mana mereka terkait. Saat ini studi melaporkan hubungan yang menjanjikan antara MSDM dan hasil, tetapi kami belum dalam posisi untuk menegaskan sebab dan akibat. Kita perlu mengembangkan 
teori yang mengintegrasikan aspek strategi dan integrasi strategis dengan sesuatu seperti teori ekspektasi untuk membuat hipotesis spesifik tentang keterkaitan. Penelitian studi kasus dapat membantu menghasilkan beberapa wawasan yang dapat diuji secara lebih luas. Demikian juga dengan studi praktik tertentu atau isu-isu seperti kualitas atau komitmen di mana teori kadang-kadang lebih spesifik. Untuk membangun hubungan, kita juga membutuhkan desain penelitian longitudinal, idealnya dengan semacam intervensi untuk mengubah praktik MSDM.

\section{DAFTAR PUSTAKA}

Arthur, J.B. (1994) 'Effects of Human Resource Systems on Manufacturing Performance and Turnover', Academy of Management Journal, 37: 670-87.

Becker, B. and Gerhart, B. (1996) 'The Impact of Human Resource Management on Organizational Performance. Progress and Prospects', Academy of Management Journal, 39(4): 779-801.

Beer, M., Spector, B., Lawrence, P., Quinn Mills, D. and Walton, R. (1985) Human Resource Management: A General Manager's Perspective, New York: Free Press.

Delaney, J. T. and Huselid, M.A. (1996) 'The Impact of Human Resource Management Practices on Perceptions of Organizational Performance', Academy of Management Journal, 39(4): 949-69.

Delery, J. and Doty, D.H. (1996) 'Modes of Theorizing in Strategic Human Resource Management: Tests of Universalistic, Contingency and ConŽ gurational Performance Predic-tions', Academy of Management Journal, 39(4): 802-35.

Dyer, L. and Reeves, T. (1995) 'Human Resource Strategies and Firm Performance: What Do We Know and Where Do We Need to Go?', paper presented to the 10th IIRA World Congress, Washington, 31 May - 4 June.

Guest, D.E. (1987) 'Human Resource Management and Industrial Relations', Journal of Management Studies, 24: 503-21.

Guest, D.E. (1992) 'Right Enough to Be Dangerously Wrong: An Analysis of the In Search of Excellence Phenomenon'. In Salaman, G. (ed.) Human Resource Strategies, London: Sage.

Guest, D.E. and Hoque, K. (1994) 'The Good, the Bad and the Ugly: Human Resource Management in New Non-union Establishments', Human Resource Management Journal, 5(1): 1-14.

Hendry, C. and Pettigrew, A. (1990) 'Human Resource Management: an agenda for the 1990s', International Journal of Human Resource Management, 1(1): 17-43.

Huselid, M.A. (1995) 'The Impact of Human Resource Management Practices on Turnover, Productivity and Corporate Financial Performance', Academy of Management Journal, 38: 635-70. 
Huselid, M.A. and Becker, B. (1995) 'High Performance Work Practices and the Performance of the Firm: The Mediating Effects of Capital Structure and Competitive Strategy', paper presented to the Academy of Management Conference, Vancouver, 6-9 August.

Huselid, M.A., Jackson, S.E. and Schuler, R.S. (1995) 'The SigniŽ cance of Human Resource Management Implementation Effectiveness for Corporate Financial Performance', paper presented to the Academy of Management Conference, Vancouver, 6-9 August. In press, Academy of Management Journal.

Ichniowski, C., Shaw, K. and Prennushi, G. (1994) 'The Effects of Human Resource Management Practices on Productivity', Working Paper, Columbia University.

Kochan, T., Katz, H. and McKersie, R. (1986) The Transformation of American Industrial Relations, New York: Basic Books.

Lawler, E.E. (1986) High Involvement Management, San Francisco: Jossey-Bass.

Lawler, E.E. (1992) The Ultimate Advantage. San Francisco: Jossey-Bass.

Levering, R., Moskowitz, M. and Katz, M. (1984) The 100 Best Companies to Work for in America. Reading, Mass.: Addison-Wesley.

Locke, E.A. and Latham, G.P. (1990) 'Work Motivation: The High Performance Cycle'. In Kleinbeck, U., Quast, H-H., Thierry, H. and Hacker, H. (eds) Work Motivation, Hillsdale, NJ: Lawrence Erlbaum.

MacDufŽ e, J.P. (1995) 'Human Resource Bundles and Manufacturing Performance: Flexible Production Systems in the World Auto Industry', Industrial Relations and Labor Review, 48: 197-221.

McGregor, D. (1960) The Human Side of Enterprise, New York: McGraw-Hill.

Miles, R. and Snow, C. (1984) 'Designing Strategic Human Resource Systems', Organizationa 1 Dynamics, Summer: 36-52.

Mowday, R.T., Porter, L.W. and Steers, R.M. (1982) Employee-Organization Linkages: The Psychology of Commitment, Absenteeism and Turnover, New York: Academic Press.

Pfeffer, J. (1994) Competitive Advantage Through People, Boston, Mass.: Harvard Business School Press.

Pfeffer, J. (1995) 'Producing Sustainable Competitive Advantage through Effective Management of People', Academy of Management Executive, 9(1): 55-69.

Porter, M.E. (1990) Competitive Strategy, New York: Free Press.

Schuler, R.S. and Jackson, S.E. (1987) 'Linking Competitive Strategies with Human Resource Management Practices', Academy of Management Executive, 1(3): 209-13.

Sivasubramaniam, N. and Kroeck, K.G. (1995) 'The Concept of "Fit" in Strategic Human Resource Management', paper presented to the Academy of Management Conference, Vancouver, 6-9 August.

Staw, B. (1986) 'Organizational Psychology and the Pursuit of the Happy/Productive Worker', California Management Review, 18(4): 40-53.

Venkatraman, N. (1989) 'The Concept of Fit in Strategy Research: Toward Verbal and Statistical Correspondence', Academy of Management Review, 14(3): 423-44. 
Walton, R.E. (1985) 'From Control to Commitment in the Workplace', Harvard Business Review, 63: 77-84.

Wood, S. and Albanese, M.T. (1995) 'Can We Speak of Human Resource Management on the Shop Floor?', Journal of Management Studies, 3(2): 215-47.

Youndt, M., Snell, S.A., Dean, J.W. and Lepak, D.P. (1996) 'Human Resource Management, Manufacturing Strategy, and Firm Performance', Academy of Management Journal, 39(4), 836-66. 